\title{
LEADER POLICY PRACTICES AND LANDSCAPES IN THE LIGHT OF THE AGENCY-STRUCTURE DEBATE: EVIDENCE FROM LEADER LOCAL ACTION GROUPS IN ITALY AND IN FINLAND
}

\author{
Fulvio Rizzo ${ }^{1}$
}

Received 25 January 2013; Accepted 20 September 2013

\begin{abstract}
This article investigates LEADER policy practices and landscapes within very different regions of the European Union: North Karelia, Finland, and South Tyrol, Italy. The qualitative analysis of this geo-institutional comparison is carried out in the light of the agency-structure debate. Such theoretical framework contributes to investigate policies on the basis of their causal/contextual conjunctures; at the same time, it cautions from the contemporary common approach to identify 'best' policy practices. In the Joensuun Seudun LEADER Local Action Group, policy processes of social engagement are encompassed by the dominating structures of 'village', and 'subpolitics'. In the Local Action Group Wipptal instead, the data suggest that the dominating structural dimensions are 'politics' and 'agriculture'. Against the background of a re-territorialized rural development, policy implementation is a unique geographical process, which cannot be left aside neither from its contextual conjunctures, nor from a broad theoretical framework.
\end{abstract}

Key words: agency, structure, institution, territory, sub-politics, politics, mountain, agriculture.

Sommario: II presente articolo prende in esame le principali caratteristiche e relativi contesti di politiche rurali implementate in due diverse aree LEADER dell' Unione Europea: Sudtirolo (Italia), e Carelia del Nord (Finlandia). L' analisi qualitativa di questo paragone geografico-istituzionale è stata effettuata alla luce del dibattito agentestruttura. Questa cornice teoretica non soltanto contribuisce ad esaminare le politiche rurali in virtù del loro contesto, ma anche mette in guardia dall' approccio piuttosto diffuso e disinvolto che consiste nell' individuare le cosidette best policy practices. Nel GAL Joensuun Seudun LEADER i processi di interazione sociale sono dominati dalle strutture del 'villaggio' e della sub-politics. Nel GAL Wipptal invece, i dati empirici suggeriscono che le strutture dominanti sono la 'politica' e 'l'agricoltura'. Sullo sfondo di uno sviluppo rurale inteso come processo di riterritorializazione, l' implementazione delle policies rappresenta un fenomeno geografico ben distinto, che non può essere dissociato nè dai relativi contesti geoistituzionali, nè da un' ampia cornice teoretica.

Parole chiave: agente, struttura, istituzione, territorio, sub-politics, politica, montagna, agricoltura.

\footnotetext{
${ }^{1}$ Fulvio Rizzo, PhD, Karelian Institute, University of Eastern Finland, Joensuun kampus PL 111, 80101 Joensuu, Finland. Email: fulvio.rizzo@uef.fi
} 


\section{Introduction}

The destructuring of the hierarchies typical of the Fordist mode of production - which, to a varying degree, has involved a rescaling of the state as a tool of global capital - has contributed to competition at all levels: for instance, as metropolitan areas compete to host global events, also rural areas of different sizes are in competition to attract tourist flows (Osti 2000, 172; Cerny 2006; Brenner 2004). At the same time, due to global processes of homogenization and neo-liberalization ${ }^{2}$, as well as technological advances, contemporary policies are increasingly exerting normative power over significant geographical distances, turning the notion of 'domestic' decision-making as a quasianachronistic phenomenon (Peck 2011; Dolowitz and Marsh 2000). The implementation of trade, industrial, monetary, agricultural, and rural policies - to name just a few - involves a wide array of governance mechanisms among international and national level institutions and domains (Peck 2011; Agnew 2001). Against this trans-national background, within the European Union the economic agenda of the Single Market and the political agenda of a European identity/integration appear to encourage localist approaches (Ray 1998). As a result of the reform of the Structural Funds in 1988, local rural development has emerged as an important element in the European Union (EU) Structural Policy (Ray 1997). A striking example of such localist agendas is given by the multi-actor, integrated, innovative LEADER ${ }^{3}$ Programme, which is currently in its fourth implementation period (LEADER I 1991-1993, LEADER II 1994-1999, LEADER + 2000-2006, and the current LEADER 2007-2013).

Similarly to what argued by Peck $(2011,774)$ in relation to the phenomenon of 'policy transfer', also the insertion of the LEADER approach in a variety of different national institutional frameworks represents a geographically-tailored experience (see also Shucksmith 2009). Its implementation has been different both within the European Union, and within other international contexts such as Africa and Russia (Uusitalo 2011). If on the one hand the literature on the implementation of the LEADER approach is reasonably vast, on the other hand, qualitative studies focusing on international geographical comparisons whose aim is to understand the interaction of local actors and their overarching geo-institutional structures are relatively rare. The latter include for instance Kull (2008), who has investigated the multi-level governance in the LEADER Programme in Germany and Finland; the work by Cavazzani \& Moseley (2001) on the effectiveness of partnerships on rural development from eight EU countries, and Ruzza et al. (2009), who have analyzed the transformations and innovations in the modalities and contents of the policies of rural development in Italy, England, and France.

This article - based on the comparison between two LEADER Local Action Groups ${ }^{4}$, one located in South Tyrol, Italy (LAG Wipptal/GAL Alta Valle Isarco) and the other one in North Karelia, Finland (Joensuun Seudun LEADER Ry) (Figure 1) - investigates policy practices and landscapes in the light of the agency-structure debate. Firstly, the social background of a variety of local actors who have been involved at some stage of their working career with the LEADER programme is taken into account; secondly, the interaction dynamics and qualitative outputs between these local actors and their overarching geographical, institutional, and territorial structures are discussed. In contrast to orthodox investigations of policies, which tend to isolate them in an institutional vacuum, the article pays attention to a variety of "geographically contingent conditions, which are operational under specific (geographical) circumstances" (Tykkyläinen 2008, 11).

As virtually all rural and regional development policies of the contemporary era, also LEADER is characterized by the 'projectification' phenomenon, which is based on the idea that projects, as forms of organization and management, have become post-modern symbols of adaptability and contingency (Sjöbolm 2006). Such mode of action has contributed to the emergence of new

\footnotetext{
${ }^{2}$ In this article neo-liberalization is intended as a "politically guided intensification of market rule and commodification" (Brenner et al. 2010, 184).

${ }^{3}$ For an in depth overview of its key characteristics, see for instance Barke and Newton (1997); High and Nemes (2007).

${ }^{4}$ The LEADER Local Action Groups are partnerships consisting of private and public actors, and they have the goal to enhance the development of a specific rural region.
} 
actors, who consist to a large extent of civil servants, experts, managers, and other holders of intellectual power sharing similar features and goals (Kovách and Kučerová2006). While the latter scholars have interpreted these new actors as the rise of a'project class', one may also conceive the 'projectification' phenomenon as one of the most visible manifestations of the 'bureaucratization' of the European lagging behind regions' development.

Three main factors have had a relevant influence on the rise of new actors who populate rural development practices (Kovách and Kučerová 2006, 8). The first factor consists of decentralization processes that are increasingly materializing in European countries, regardless of their historical, political, and cultural backgrounds. Administrative changes have been the result of the emergence of new regional and rural development initiatives at the EU level. Another factor that has affected the rise of professional actors has been the emergence, alongside the welfare state, of a variety of governance mechanisms: public, private, and voluntary sectors increasingly work together in diffused power contexts (Shucksmith, 2009). At the same time, the importance of civil society's participation in EU and national development policy systems has increased, and one of the most relevant reasons for that is the distrust of a large number of European citizens towards the institutions of representative democracy (Ruzza 2009, 37).

Last but not least, the third factor that has influenced the rise of qualified expertise in rural development is the culture economy; rural developers are responsible for supporting local values that have a key role in successful development processes. Local values include traditional foods, regional languages, historical sites, and local knowledge (Ray 1998; Kovách and Kučerová 2006). The European Union, through the LEADER programme for instance, supports territories to select and implement those strategies that emphasize the exploitation of local resources.

In the light of these preliminary considerations, whose aim has been to highlight both the transnationalization of contemporary policies, and the 'peopling' of lagging behind regions' development by new, professional actors, this article is structured as follows. Section 2 reveals the material and methods employed to motivate, investigate, and analyze the empirical data. Section 3 is theoretical; firstly, it opens the discussion on the main debates concerning agency and structure. Secondly, it defines the LEADER local actors through the contribution of the concepts of class and sub-politics; thirdly, it interprets structure within the framework of territory, and institutions. Section 4.1 and 4.2 are devoted to the Finnish case study, while Section 5.1and 5.2 tackle the analysis of the Italian case study. Section 6 deals with the discussion and conclusions, which emphasize the relevance, and the contribution of this geographical comparison concerning the interaction of local actors and their overarching geographical, territorial, and institutional structures.

\section{Material and methods}

This article is built upon my $\mathrm{PhD}$ thesis, which has been published in 2012. Alongside secondary literature, the key data is provided by face-to-face semi-structured interviews. This empirical material has been collected throughout the period 2008-2011 in Finland and in Italy with a variety of professionals who, at some stage of their working career, have been involved in the design and/or the implementation of the LEADER Programme. The interviews taken into account in this article are twenty-three for the Finnish case study, and nineteen for the Italian case study.

The choice of the Joensuun Seudun LEADER and LAG Wipptal/GAL Alta Valle Isarco as investigation areas has been undertaken in the light of their intrinsically diverse agencystructure dimensions and interactions: while the former has to be interpreted within the Nordic context, the latter represents a case where the Central European and the Southern European cultures meet. The two case studies have fed each other in the process of data generation and analysis. It is for this reason that the encompassing methodology of this article is grounded theory, which has two main characteristics. Firstly, it is based on 'constant comparison', whereas data are collected and analyzed at the same time (Corbin and Strauss 1990, 9); 
secondly, it is built upon 'theoretical sampling', which means that the decision to select certain type of data is undertaken following the theory being constructed (Suddaby 2006).

The interview material has been analysed through thematic, and interdiscursive analysis. Thematic analysis is based on the devising of macro-propositions and the coding of key words; firstly, the so- called 'descriptive codes' have been identified, whose goal is to emphasize the most recurrent perceptions by the interviewees; secondly, 'interpretative coding' has been undertaken by grouping together 'descriptive codes', which share common interpretations; thirdly, the 'overarching themes' of the interviews have been abstracted in order to link them to the theoretical issues of the agency-structure debate (interdiscursive analysis) (Fairclough $2004,3)$.

\section{Theoretical background}

Similarly to Sibeon $(2000,290)$, the theoretical starting point of this article is based on a flexible ontology that assumes that empirical investigation should be carried out through the mutually shaping interactions between agency and structure. As Layder (1998) suggests, such flexible ontology conceives the social world as both multi-dimensional, and stratified, being characterized by a series of domains interrelated to each other. A core element of ontological realism is retained by critical realism, which is the theoretical perspective according to which "behaviour and experience are seen to be 'generated by' underlying structures such as biological, economic or social structures... which may impact on our lives" (King and Korrocks 2010, 9).

Figure 2 illustrates the theoretical framework of the article; within the encompassing, macroscale theory of critical realism, the LEADER approach is interpreted in the light of the interaction dynamics between agency and structure. To a broad extent, agency may be defined as a process of social engagement that is situated within the flow of time, and to be more precise, within a variety of temporalities, "which can be said to be oriented towards the past, the future, and the present at any given moment" or at any emergent situation (Emirbayer and Mische 1998, 963-964). As for structure, Sewell $(1992,1)$ argues that this term "empowers what it designates": structure is implied in its transitive verbal sense, which means that structure generates in a way or the other some aspect of social existence. To a more specific level, in this article the concepts of social class and sub-politics contribute to the definition of agency, while the 'structure' dimension is explained in terms of the territory and institution concepts.

The relationship between agency and structure is one of the most debated issues within social science and social theory (Fuchs 2001): the core of this debate is centered on whether, and to what extent these two entities can be separated. According to Sawyer (2002), Giddens (1979, 4, 40-56) supports the inseparability thesis, which implies not only that social structure cannot be analytically isolated, but also that properties of individual activity (reasons, intentions, mental states) cannot be analytically isolated; this is because "the notion of action and structure presuppose one another" $(1979,53)$. Giddens also argues that inseparability implies the impossibility of social causation and laws (1984, 172-179, 343-347). As a counterargument to Giddens' inseparability claim, Layder (1987, 31-32 in Sawyer 2002) is in favour of an analytic dualism between individual action and social context, which allows for a greater interplay rather than interpenetration between individual and society (Archer 1995 in Sawyer 2002). 


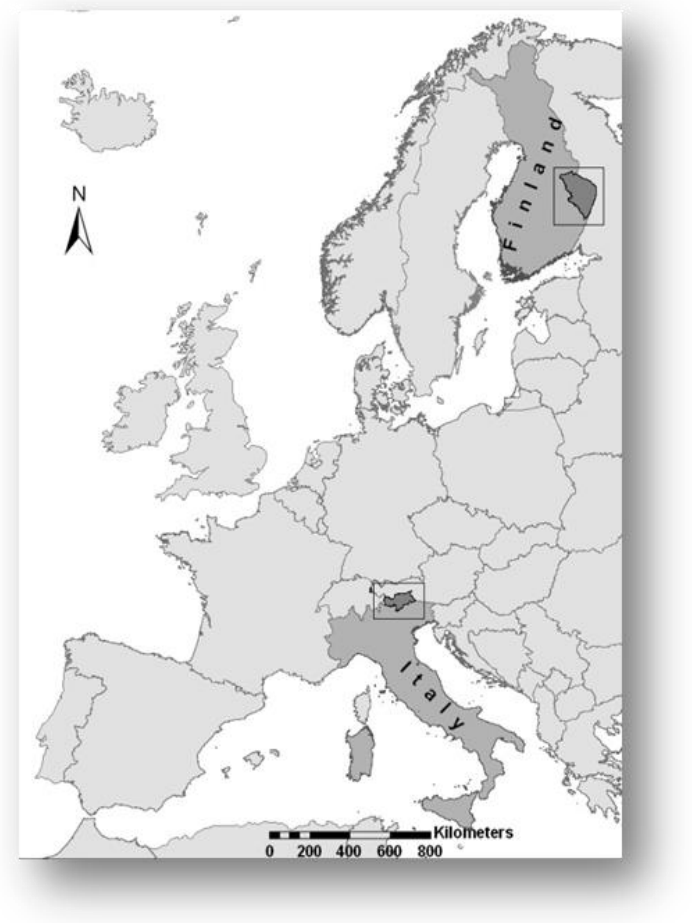

Fig 1. Location of North Karelia and South Tirol.

\section{CRITICAL REALISM}

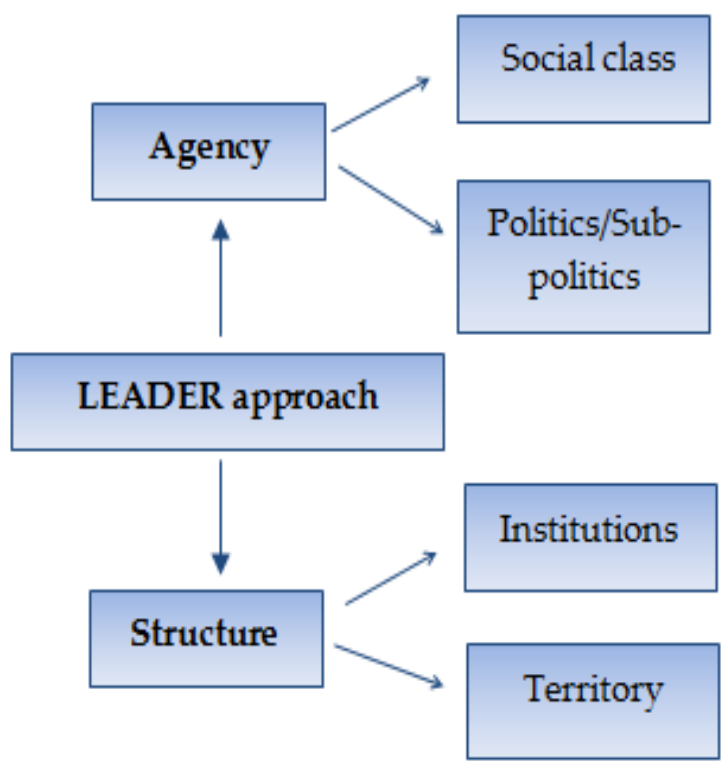

Fig 2. Theoretical framework of the article.

For the purpose of this article, analytic dualism allows for a better theorization of the nature of the causal interaction between these two entities, as well as of the nature of constraining forces and explanations of internal motivations (Sawyer 2002). Such reasoning is in line with the ideas of critical realism, which state that social structure pre-exists, and is a necessary condition to agency, and thus it is not the deliberate result of agency (Lewis 2002): "persons make their microworlds but not their macroworlds. Actors do act, but they do so under circumstances not of their own choosing. Actors do define, and redefine, situations, but there are structural limits on what can be accomplished and changed in this way" (Fuchs 2001, 24). Further, critical realists claim that the agency-structure relation has to be interpreted historically: "every person is born into a world of antecedent social structures, learning a language, and entering a culture and mode of economic organization that are not of their own choosing" (Lewis 2002, 19). It is for this reason that this article pays attention not only to geographical, but also to historical conjunctures of policy practices and landscapes.

In order to investigate the local actors who have characterized the LEADER Programme in the Joensuun Seudun LEADER and the LAG Wipptal/GAL Alta Valle Isarco, agency is interpreted through the concepts of social class and sub-politics. In the contemporary era, the concept of social class - "conceived of as the sum of nuclear familial situations, which resemble one another and are differentiated from other class-typical 'family situations' (those of the upper class, for instance)" (Beck et al. 1994, 13) - seems to have lost its momentum and it is mostly rooted in the past; this is due to the fact that the post-war development of the welfare state has led to two interlinked processes. On the one hand, people have been uprooted from traditional class ties and family support; on the other hand, it is people responsibility to produce and stage their own destiny and biographies within the labour market, along with the related risks, opportunities, and contradictions (Beck et al. 1994; Beck and Beck-Gernsheim 2005).

However, Kovách and Kučerová (2006) argue that specific insights of Weber and Marx argumentation on social class can be useful to the understanding of LEADER actors. Marx conceived human labour as a commodity; thus, it has the capacity of producing new values. This is exactly the case of the project class of the LEADER Programme, who brings new values to society through project activity. From a Weber point of view, the project class "is a group of people who share a common opportunity to achieve a high and prestigious position on account of their mediatory role" (Kovách and Kučerová $(2006,7)$. 
Another concept that is useful to explain the rise of new actors within rural development practices is sub-politics, defined as politics positioned outside the traditional representative institutions of the political systems of the differentiated modern society (Beck 1996, 18; see also Holzer and Sørensen 2003, 80). The term sub-politics differentiates itself from politics because the former lacks a key feature of the latter: legitimization through democratic procedures (Holzer and Sørensen 2003). Such differentiation has to be read within the denationalization, delocalization and trans-nationalization of business and the state, which have led to a redefinition of democracy within the global age (Beck 2006, 237). Additionally, Beck et al. $(1994,23)$ claim that sub-politics implies the shaping of society from below, with a decrease in central rule and at the same time growing opportunities for citizens, social movements and expert groups. As the key actors of the contemporary global society move out of the national arena, with the consequent loss of national sovereign and national democracy, the selfdetermination and participation of thinking and acting people assume an increasingly important role worldwide (Holzer and Sørensen 2003, 80).

To what extent and how the rising techno-economic power embodied by the sub-political world is challenging the political sphere? One of the ways to answer this question is to interpret the 'structure' dimension in light of the concept of territory, and of the concept of institution. In this article, territory is a physical system, which is given by geographical location, as well as by morphology, climate, and eco-system. The physical system defines the range of the possible models of development that can be undertaken. Further, the territory can be seen as a system of social, economic, political, and cultural relationsamong subjects who live in a specific area, as well as the actions that these subjects carry out to solve a problem and/or to invest local resources (Ciapetti 2010; Salvato 2006). In the latter regard, Ray (2001, 279) envisages rural development as a re-territorialization process, whereas "enterprises, Local Authorities, development agencies are variously involved in the creation of territorial, neo-endogenous initiatives which are both opportunistic of circumstances and responsive to the imperative of the emerging governance of western society."

Within such re-territorialization setting, a key structure which may limit or enable both human and/or social agents is provided by institutions. Institutions limit uncertainty by structuring everyday life, and they represent a guide to human interaction, whether it is political, social, or economic (North 1990, 3-4). Thus, institutions are not only political and administrative organizations, but according to the more hybrid new institutionalist point of view, they are also "a set of routines, norms, and incentives that shape and constrain individuals' preferences and behaviour" (Lowndes and Wilson 2001, 631). As the system may have the tendency to shift from hierarchy to markets, LEADER is an example whereas the public sector may be releasing part of its authority to market regulations (Osti 2000, 172).

To summarize, in this article the theoretical dimensions of agency and structure, which contribute to the investigation of a geographical comparison of policy practices and landscapes, have been analytically decomposed in order to facilitate the understanding of their reciprocal interactions.

\section{JoensuunSeudun LEADER Ry}

\subsection{Key contextual conjunctures structures}

Joensuun Seudun LEADER - located in North Karelia, in eastern Finland (Figure 3) - is characterized by two different types of rural areas. Just outside the boundaries of the city of Joensuu (which is not part of the LEADER area), there is a bidirectional commuting belt (both from the city to the countryside, and vice versa), which is growing in population. The other type of rural area instead is remotely and sparsely populated, and it is losing population. This phenomenon is partially caused by migration, as well as by the negative ratio of births to deaths (JoensuunSeudun LEADER Yhdistys 2007). 


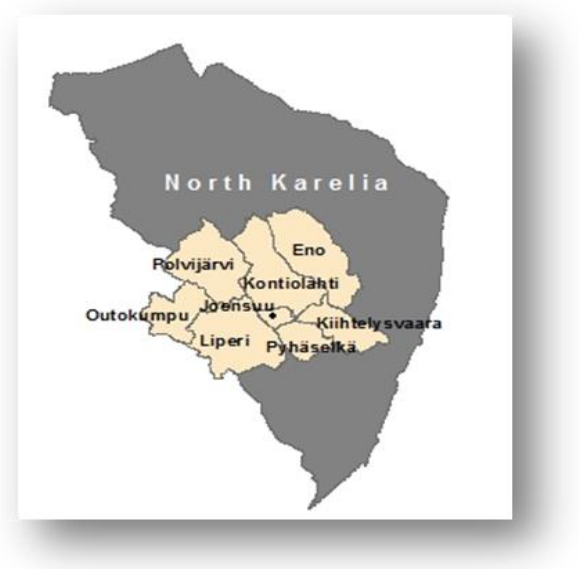

Fig 3. LAG JoensuunSeudun LEADER+

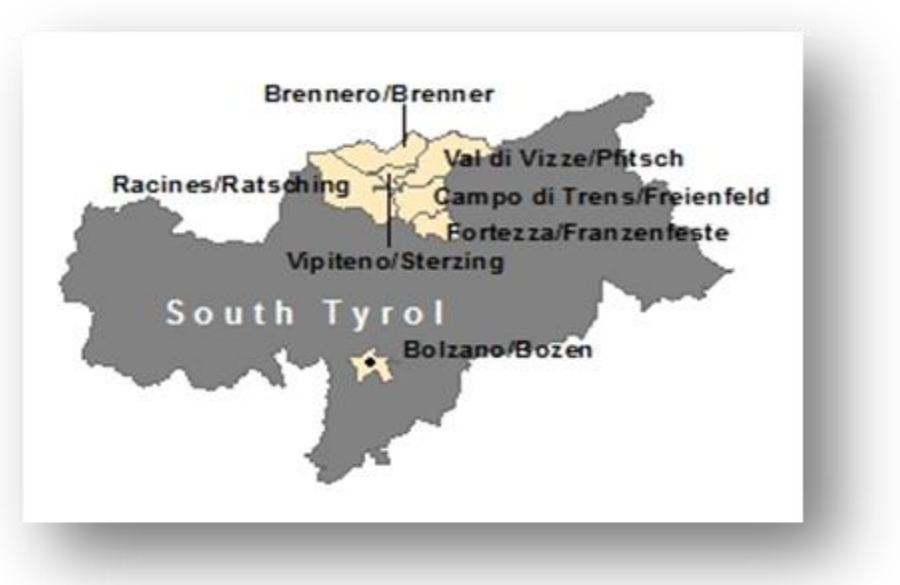

Fig 4. LAG Wipptal/GAL Alta Valle Isarco LEADER+

Within the Nordic context, scholars investigate socio-economic development of a predominantly rural region such as North Karelia in light of three co-existing specificities: demographic sparsity, peripherality, and cold climate (see for instance Gløersen et al. 2005; ESPON 2010). Also, forestry, as a physical system, has affected this region at the cultural, social, and economic level (the share of forest is $84 \%$ of the total surface area, $17763 \mathrm{~km}^{2}$ ).

Within this territorial context, structuring dimensions have been occurring bothat the level of civil society, and at the level of policies. At the level of civil society, especially from the 1970s onwards, the countryside of North Karelia has been characterized by village action as a key institution structuring development. Hyyryläinen $(2000,112)$ defines village action "as part of the historical transformation of Finnish voluntary action: cooperation in the village community developed from voluntary work to modern voluntary action and then to local development". The structural changes in agriculture led to the migration of hundreds of thousands of Finns from the northern and eastern parts of Finland (including North Karelia) to the industrial centers of the South, as well as to Swedish industrial towns (see for instance OECD 2008).

As a consequence of out-migration, the most relevant transformation in civil society was the emergence of village action, which was supported by theacademic world with the launch of the "Village Research 76" project in the 1970s;strong cooperation between researchers and the village movement representatives subsequently started to take place (see Hautamäki 1989). Alongside the emergence of village action in the remote eastern and northern areas of the country, the 1970s and 1980s saw the emergence of the public sector as the main engine of growth and the decline of agriculture and forestry (Lehtola 1995 in Pyy and Lehtola 1996).

At the level of policies, "Finland is one of the pioneer countries in naming as rural, and building an institutional framework for, and adopting policy tools targeted to rural areas, without a sectoral perspective" (OECD 2008, 91). These policy tools have been traditionally dominated by civil servants as key human agents; this is especially true after Finland joined the EU. Based on an inquiry conducted between 1992 and 2008 for instance, Hyyryläinen et al. (2009) state that the members of the Rural Policy Committee ${ }^{5}$ include a high percentage of civil servants as well as academics, interest groups, and NGOs; however, no politicians have been involved in this committee. Looking at more in depth at one of the theme working groups of the Rural Policy Committee, such as the 'local development theme' working group (examined period 20112012), among its 49 members (half official members and half vice-members), public administration dominates with 27 members, followed by civic organizations, interest groups, and municipal organizations (six members for each group), and academics (four members). No

\footnotetext{
${ }^{5}$ The Rural Policy Committee is the responsible organ for rural policy in Finland; it consists of 9 ministries, a number of public organizations and private actors. Starting from 2012, the institutional configuration of the Rural Policy Committee has changed, since it has been transferred from the Ministry of Agriculture and Forestry to the Department of Regional Development of the Ministry of Employment and Economy. At the same time, however, the LEADER funding method has remained under the control of the Ministry of Agriculture and Forestry.
} 
politicians are involved in the group. Public administration includes representatives of the Ministry of Agriculture and Forestry, Ministry of the Environment, Ministry of Justice, Ministry of Employment and the Economy, Centres for Economic Development, Transport, and Environment, as well as the Agency of Rural Affairs, and the Rural Network of Finland. Among the interest groups, three are from farming organizations (two from the Central Union of Agricultural Producers and Forest Owners, and one from Pro Agria), and three from rural/village development organizations (Finnish Village Association, ELARD/ European LEADER Association of Rural Development).

Within the context of the LEADER+ Programme, one key reform by the LEADER civil servants at the national level has been the tripartite structure of the LEADER Local Action Groups, according to which one-third of the partnership is composed of village associations, one-third by municipalities, and one-third by local citizens. The goal of this structure has been to prevent the dominance of the "old" government structure (municipalities) in favour of the "new" local development of village associations. This reform clearly shows how agency, as a process of social engagement, has a powerful influence in guiding and shaping structure dimensions as village action and development. At the same time, agency is encompassed by the long tradition of rural policy-making and practices in Finland, which reflect the characteristic of a sparsely populated territory (see for instance, Schmidt-Thomé and Vihinen 2006).

\subsection{Policy practices and landscapes}

The Joensuun Seudun LEADER Ry Local Action Group was established as an informal association with no official status; its foundation took place in the spring of 1995 by a group of about 15 to 20 people with different backgrounds and networks (such as village activists, entrepreneurs, municipal officers and researchers), who collected ideas for the LEADER II development plan. It acquired official status as a registered non-profit association in June 1996 at a meeting of 86 participants (LEADER Achievements...2007).

In the LEADER+ period (for its main facts see Table 1), the LAG board included 10 members from the municipal sector, which included the 'countryside secretaries' and politicians at the municipal level, 17 members from different organizations (mostly village associations, especially $4 \mathrm{H}$-yhdistykset), and 11 active local residents (Joensuun Seudun LEADER Yhdistys 2007).

\begin{tabular}{|l|}
\hline Surface area: $5,692 \mathrm{~km}^{2}$ \\
\hline Population: 56,000 inhabitants \\
\hline Number of municipalities: 7 \\
\hline Total funds spent: 7.5 million $€$ \\
\hline $\begin{array}{l}\text { Strategic objectives: the main goal of the programme in this area was the improvement of the quality of life } \\
\text { of people living in the countryside, and also the strengthening of the diversity, the plurality, and the } \\
\text { activeness of its remote regions. }\end{array}$ \\
\hline Number of projects: 238 \\
\hline $\begin{array}{l}\text { Types of projects: the LAG has funded projects with a clear 'local' orientation, for instance, excluding large } \\
\text { organizations such as the North Karelia Educational Federation of Municipalities, or Pro Agria (Joensuun } \\
\text { Seudun LEADER Yhdistys } 2007) \text {; the goal has been to finance projects for young people and entrepreneurs } \\
\text { within villages as well as projects which promote the idea of city residents and tourists visiting the } \\
\text { countryside. }\end{array}$ \\
\hline
\end{tabular}

Tab 1. JoensuunSeudun LEADER + mainfacts.

On the basis of thematic analysis (whose code levels are shown in Figure 4), the empirical data extracted from the interviews suggest that the LEADER approach in the Joensuun Seudun $\angle E A D E R$ has been characterized by two main overarching and interdependent themes: villages, and subpolitics. As for the 'villages' theme, the main interpretive code is given by the 'cultural, and social power of villages', while for the 'subpolitics' theme, the key interpretive codes are cooperation, and competitiveness.

Upon the investigation of the professional background of the twenty-three interviewees, the vast majority consists of civil servants (16 of them), who, at the time of the interviews, were working 
either for the public sector at the national, regional, and local level (Ministry of Agricultural and Forestry, Employment and Economic Development Centres, municipalities), or for rural organizations, including LEADER Local Action Groups, the Regional Village Association, and the Union for Rural Education and Culture. The other interviewees include three researchers, and five rural entrepreneurs. Only two individuals have been at some stage of their working career involved in politics; in contrast, most interviewees have covered during their professional life a multiple role within rural development practices. Firstly, this means that all of them have had experience with development projects, especially with LEADER projects; secondly, nine of them have been directly involved in village movement activities, whether as activists, or as developers (or both). Based on the historical, institutional and territorial conjunctures discussed in section 4.1, the social composition of the interviewees reflects the relevance of sub-politics, with growing opportunities for citizens, social movements, and expert groups who shape the society from below.

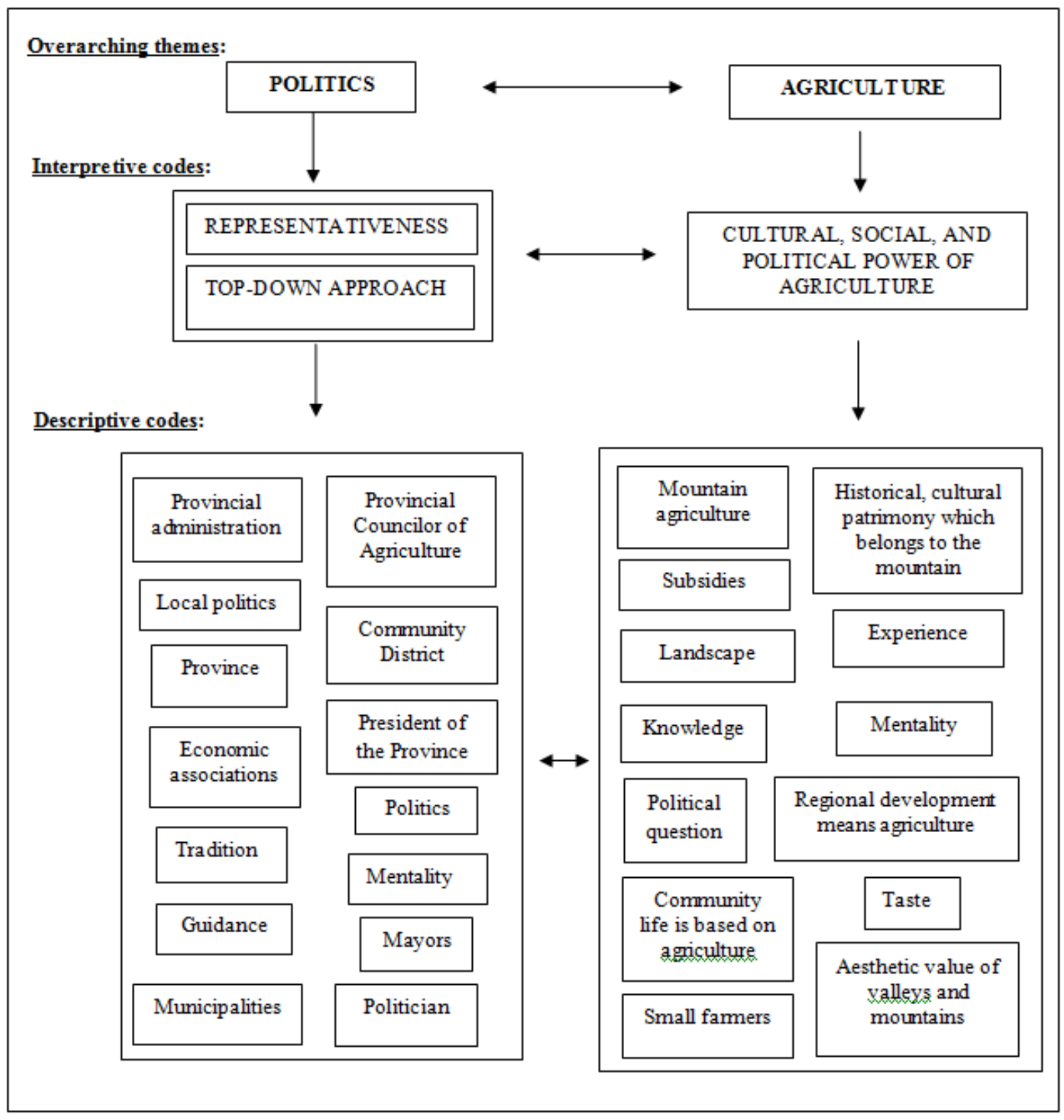

Fig 5. Thematic analysis for the Joensuun Seudun LEADER.

Within the Joensuun Seudun LEADER the importance of village development and action is reflected by the active cooperation between this LAG and the Joensuu Union of Rural Education and Culture, a state-centred and politically sponsored (by the Center Party) association, which 
organizes cultural courses for village organizations and at the same time activates citizens together with Joensuun Seudun LEADER. Its function is to help village organizations design their village plans and advise them on how to use their budget. The interaction of the 'village' structural dimension with the LEADER Programme structural dimension has given the opportunity for villages to have access to new resources for their projects and plans, especially in light of the municipalities' financial difficulties. At the same time however, the LEADER programme has brought competitiveness, shifting the responsibility of development to the local level, as remarked by one interviewee: "the all system is based on active people... if you are active you are the winner, if you are passive you are a loser. It is not a very democratic system, it is a bit against the idea of the Welfare State".

It is not anymore the duty of politicians to handle development; rather, it is the unrepresentative world of sub-politics that handles projects and plans. If on the one hand competition rewards the skilful and active agents, on the other hand it inevitably excludes others. Not all village associations, as a rural researcher remarks, have been able to catch the opportunity of LEADER funding in North Karelia. North Karelian villages can be divided in three groups: 1/3 of the 230 villages present in the territory can be classified as very active, $1 / 3$ as running the basic village activities, and $1 / 3$ as not active. Firstly, a few interviewees have suggested that some villages did not want to commit themselves to the LEADER process and its connected bureaucracy, they wanted to remain free organizations. Secondly, when villages did become registered associations, not all of them have been willing to start development projects. This has depended on whether people in the villages are active, and whether they have time to commit to local development (or as a rural secretary remarks, there is a 'community spirit' within the village). The villages that had already professional and managerial skills have had greater opportunities to access to funding.

The data collected also show that farmers' involvement in the LEADER Programme has been very thin. In the LEADER+ period (2000-2006) there were no board members in the Joensuun LEADER Local Action Group officially representing the Central Union of Agricultural Producers and Forest Owners (also known as MTK); however, three board members representing the public sector in the LAG were at the same time MTK representatives. Among the 238 projects of LEADER+ about five of them were related in one way or another to the agricultural sector. These data correspond to the broader national context: a report from the Ministry of Agriculture and Forestry (2011) states that the majority of the support given through local action groups was given to non-farming small entrepreneurs.

Regardless of the LEADER Programme, the increasing polarization between the 'active' and the 'passive' agents is exacerbated by the structural weaknesses of the contemporary countryside, which are given by increasing ageing, and above all, by policies that have been favouring on the one hand the secularization of agriculture (uprooting this activity from its historical bonds to the territory), and on the other hand the concentration of people to urban areas to satisfy market logics.

\section{LAG Wipptal/GAL Alta Valle Isarco}

\subsection{Key contextual conjunctures structures}

LAG Wipptal/GAL Alta Valle Isarco - located in South Tyrol' ${ }^{6}$, in northeastern Italy (Figure 4) has witnessed a period of restructuring that has followed the dismantling of border structures upon the implementation of the Schengen Treaty in 1998 (Gruppo d' Azione Locale Wipptal 2008). This Local Action Group, as well as South Tyrol as a whole, is characterized by

\footnotetext{
${ }^{6}$ South Tyrol is a predominantly German-speaking autonomous province (Autonomous Province of Bolzano/Bozen, Alto Adige/Südtirol). It was previously a component of the Austro-Hungarian Empire, as part of a greater Tyrol region constituted by what are today North and East Tyrol (Austria) and Trentino (Italy). It became part of Italy in 1919 when the Austro-Hungarian Empire was dissolved after World War I. Since then, its population became an ethnic minority within the Italian state with a clearly delineated homeland (Markusse 1997, 79). On the basis of the last census (2011), the German-speaking group represents $69.41 \%$ of the total population, Italians $26.06 \%$, and Ladins $4.53 \%$ (IstitutoProvinciale ... 2012).
} 
a mountainous ${ }^{7}$, alpine setting. At least $40 \%$ of South Tyrol's surface is located at an altitude higher than 2000 meters (Provincia Autonoma di Bolzano 2009). According to the criteria of altitude and steepness (see EU Council Regulation 1698/2005), about 6,864 $\mathrm{km}^{2}$ or $94 \%$ of the total surface area in South Tyrol is considered mountainous. The remaining $6 \%$ is comprised of areas located at the bottoms of valleys. As a consequence, only a small portion of the province can be inhabited and exploited economically (Lechner et al. 2010). Especially remote alpine valleys, such as the ones located in $L A G$ Wipptal, have a delay in their development.

In addition to the mountainous bond, which has clearly defined spatially, culturally, and economically the South Tyrolese identity throughout history, the local rural society is built around the centrality of the Bauer (farmer) as a key human and social agent. In South Tyrol, the centrality of the Bauer has historically implied a rigidly hierarchical and vertical family model. In turn, this is reflected in a strongly hierarchical and polarized conception of power, in which the patriarchal model characterized by a top-down perspective inhibits bottom-up mechanisms (Fait and Fattor 2010). However, the centrality of the Bauer would not exist without a link to another deeper and holistic centrality: that of belonging to the land, or better, to land property and its indivisibility. A key structuring dimension that has historically characterized agriculture in South Tyrol is the legal institution of the Closed Farm (in German Der geschlossene Hof, in Italian masochiuso). This institution provides that "upon the farmer's death, the farm is not subdivided among the heirs, but it is attributed to only one person, usually one of the coheirs, called heir contractor (Anerbe)" (Mori and Hintner 2009, 6). The other heirs have only the right to compensation. Gatterer (2007) states that in the aftermaths of the Second World War this institution represented the first step to consolidate the South Tyrolese minority in Italy. The Closed Farm has survived until contemporary days, since it has been part of the local custom and culture since generations.

At the level of policies, the impact of CAP reforms on Italian rural policy was that rather than creating a new Italian strategy for its lagging regions, Italy's rural development strategy has to a large extent become dependent on EU regional and agricultural policy (OECD 2009, 19). The Italian rural programmes ${ }^{8}$ under the Ministry of Agriculture have a tendency to focus on the primary sector, rather than on a territorial approach. In spite of the fact that the decisionmaking arena has expanded (Osti 2000), the agricultural trade associations have a strong role in defining regional rural development programmes; their lobbying activity also has the goal of maintaining their status, and at the same time opposing economic diversification and other intervention measures directed towards the territory as a whole. Relations with local politicians are also quite important both to determine resource use at the regional level, and to achieve successful results (OECD 2009, 19-100).

\footnotetext{
${ }^{7}$ Borghi $(2006,21)$ claims that the Italian mountain is not a heterogeneous entity; rather, Italian mountains exist and, within them, there are categories that, from a social and economic/productive point of view, are very different from each other. These categories are linked to the geomorphic, historical, and economic characteristics of the territory. As well, mountain areas are delimited by natural barriers, which define in a clear way the borders of a territory; such natural barriers in turn define identities, which have the tendency to look inwards. As is the case of South Tyrol, "the physical environment can be conceived as a bond, as a limit that physically encompasses the territory, makes survival difficult, sculptures the identity, and defines the sense of belonging. The alternative has always been either to adapt to these strong bonds or emigrate" (Salvato 2006, 247).

${ }^{8}$ Unlike Finland, which is a unitary state with one national rural policy, in Italy, as a regional state, rural development policy is planned and implemented through sectoral administrations (regional agricultural departments).
} 
Within South Tyrol, rural development has been intertwined with the history and evolution of the ethnic groups present in this territory. Until the 1970s, both industrial and rural development was neglected in the province ${ }^{9}$. South Tyrol experienced profound structural changes starting in the 1970s, when the new Autonomous Statute ${ }^{10}$ of 1972 was introduced. The province has since invested heavily in its remote rural areas, especially focusing on the improvement of road infrastructure, which has allowed farmers to remain in their huts and develop rural tourism, and a wide-ranging urban policy, which promoted the establishment in the valleys of numerous handicrafts and industrial centres.

\subsection{Policy practices and landscapes}

When the Wipptal district was chosen in 2001 by the Provincial Government for the implementation of the LEADER+ Programme (for its main characteristics, see Table 2), an ad hoc cooperative was established in January 2002 to host both the Local Action Group, as well as other EU funds, including INTERREG, and the European Social Fund. The members of the Local Action Group were appointed by an act of the District Community. In the LEADER+ Period, the Wipptahocal Action Group was composed by 24 members, of which 12 were representatives from the public sector, and the other 12 representatives from the private sector. As for the latter, representatives came from key associations of the district, in particular the Tourism Consortium of Isarco Valley, the Traders' Union, the Craftsmen Union, the District Association of Agriculture, the Liberi Professionisti (Professionals), the Vipiteno Forestry Inspectorate, and the Youth Center.

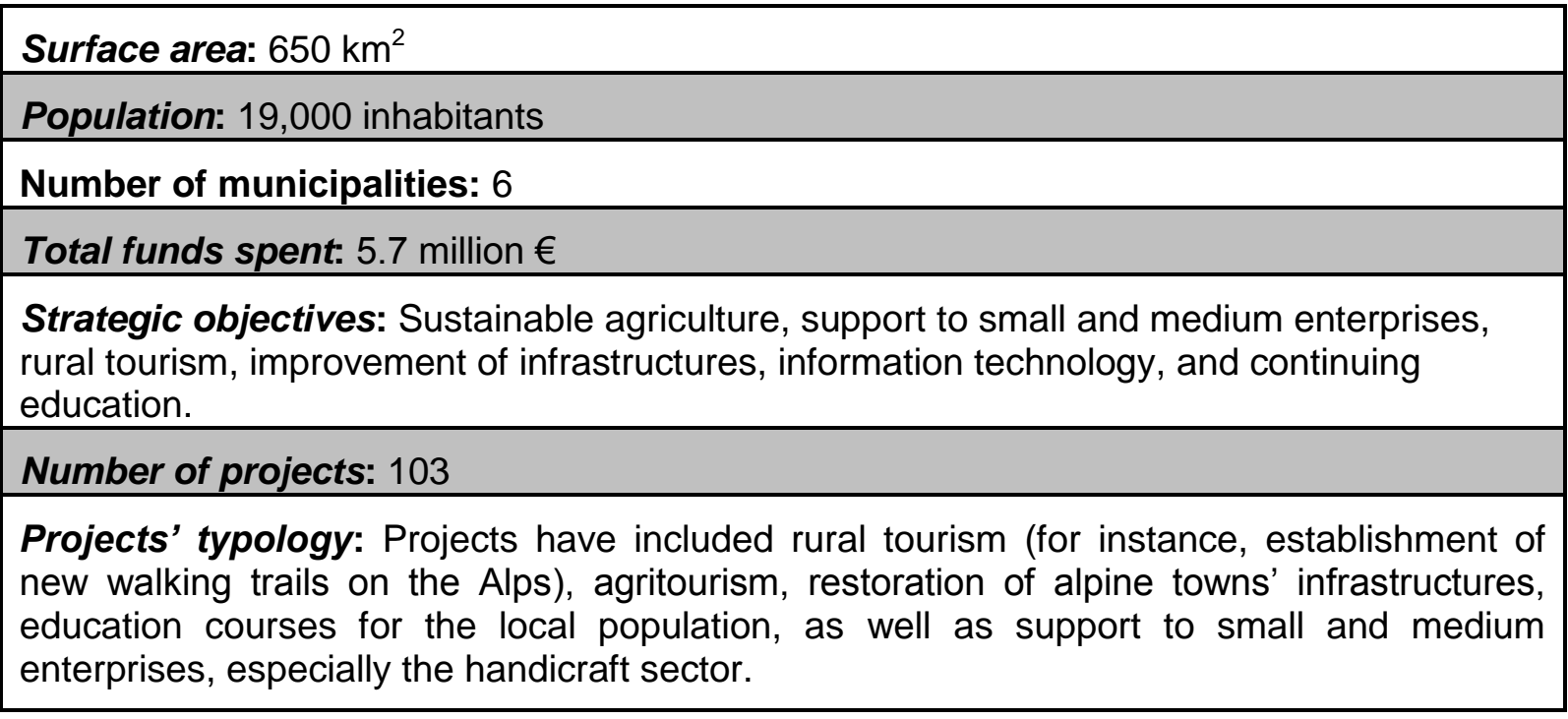

Tab 2. LAG Wipptal/GAL Alta Valle Isarco LEADER+ main facts.

On the basis of the thematic analysis undertaken in the analysis of the interviews (code levels shown in Figure 6), the empirical data suggest that the LEADER approach in this province has been characterized by two main overarching themes closely related to one another: politics and agriculture. In regard to the theme of politics, the main interpretive codes are given by the top-

\footnotetext{
${ }^{9}$ During the Fascist period, which saw an attempt to Italianize any aspect of South Tyrolese daily life, from institutions and schools to names of single individuals, South Tyrolese socio-economic life reached its lowest point in history (Lechner et al. 2010). The most fundamental aspect of the Italianization Programme was the implementation of an industrial area in the capital of the province, Bolzano/Bozen, in order to encourage Italians to settle in the area. With the establishment of the 'Zone', the Italian population grew from 36,734 in 1921 (16.1\%), to 78,201 (25.8\%) in 1939 (Alcock 1970). While Bolzano can be considered an Italian enclave, where the Italian-speaking ethnic group dominates, and is run autonomously by its political representatives, the rest of the territory is German-speaking; as a result, the ethnic party Volkspartei chiefly gathers its support in the rural territory; political attention goes to the rural areas, because politically this is crucial.

${ }^{10}$ In 1972, after years of negotiations, South Tyrol and Austria, on the one hand, and the Italian Government, on the other, were able to approve a Second Autonomy Statute known as 'Das Packet' or 'Il Pacchetto', which improved significantly the living conditions of the South Tyrolese (see Markusse 1997).
} 
down approach, which has historically been the main method of development (as well as the main political approach) in the province, and by the concept of representativeness.

Out of the nineteen interviewees taken into account for the purpose of this article, only four of them (the two members of the LAG staff, one professor, and one representative of the tourism sector) had experience with projects, and to a broader extent, with rural development ${ }^{11}$. The most striking characteristic of the Italian case study is the relevant presence of informants who have a background in politics, especially the majors of the different municipalities involved in the Local Action Group. Another characteristic which noticeably distinguishes LAG Wipptal from JoensuunSeudun LEADER Ry is that within the former most interviewees have had the same job since their working career started. Such characteristic reflects the broader picture of the job market in Finland and in Italy, being the former way more flexible than the latter.

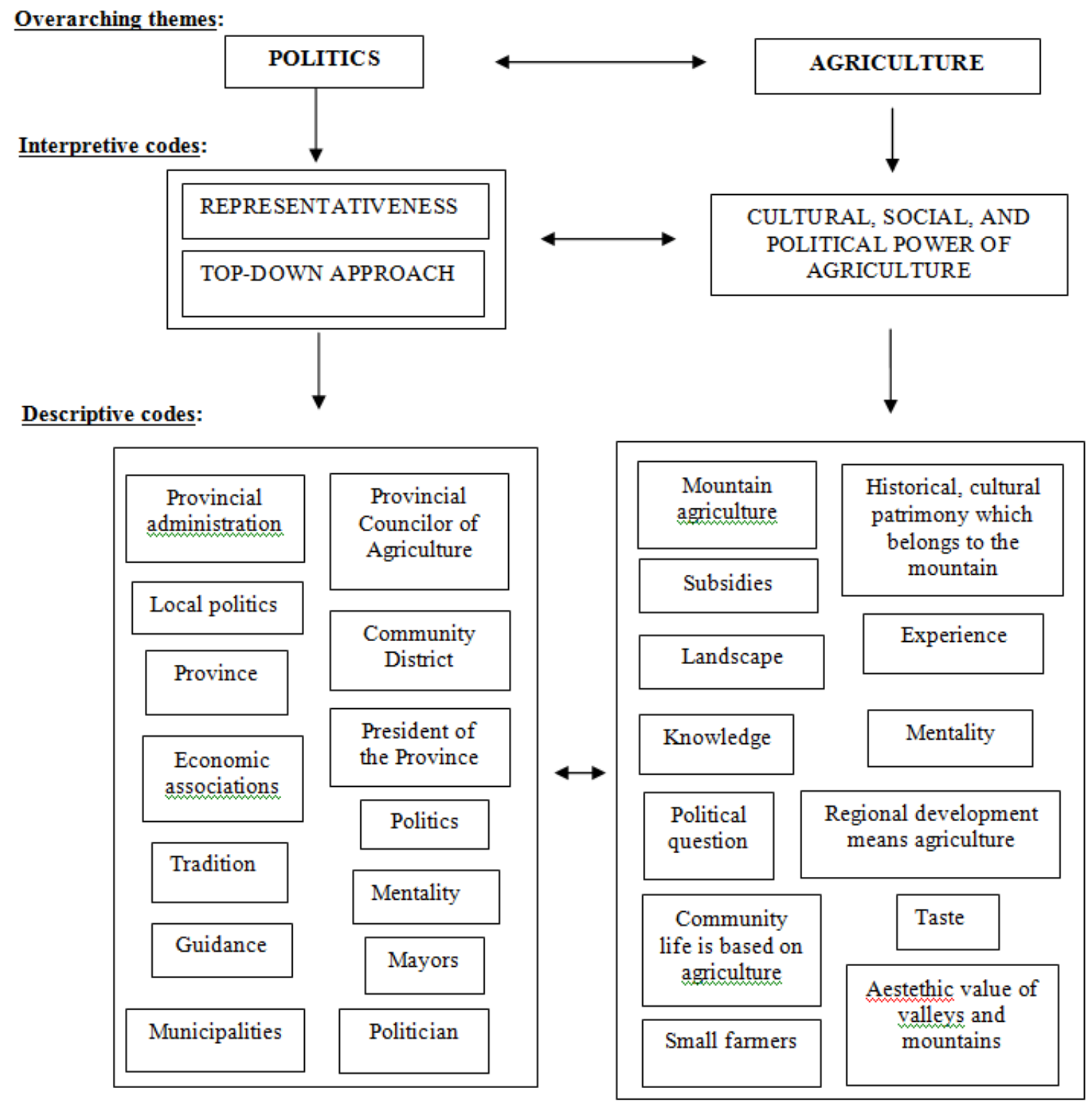

Fig 6. Thematic analysis for the LAG Wipptal/GAL Alta Valle Isarco.

\footnotetext{
${ }^{11}$ Both in South Tyrol and in Italy, the job position of rural developer and/or rural activist as it is known in Finland hardly exists. This is due to the fact that Italy is a strongly urbanized country; as a result, there is a weak tradition of rurality at the theoretical, cultural, and policy-making level.
} 
On basis of the respondents' argumentations, the data suggest that 'development' is aprerogative, almost an exclusive right of the public sector, including the various levels of government and governance (province, municipalities, and the district community), as well as administration. It is the municipalities that are supposed to handle development policies as well as being beneficiaries; 'representative democracy' is the main guide overseeing development. Thus, it is suggested that a real bottom-up approach cannot exist in South Tyrol because representativeness is a key dimension in public life: "people are used to having a guide". In this province, and in general in the Italian context, people seem to trust groups of individuals that represent certain interests, rather than the initiative of single individuals in legitimizing the creation of any public body or organization, as noted by an interviewee: "I also would feel worried if somebody I don't even know puts up an organization like a local action group. A single individual, by definition, cannot be good as such. He could be bad. There is a high risk that he does his own business in that organization ..... In the Italian context as well, research conducted for instance by Petrella (2009) on some Italian local action groups indicates that the bottom-up aspect in the constitution of local action groups is neither so evident nor spontaneous. In spite of a background dominated by politics, through the dimensions of representativeness and the top-down approach, LEADER, as a novel instrument in the South Tyrolese territory, has certainly stimulated a bottom-up culture. Respondents mostly agree that the added value of LEADER's implementation has been that of creating a common ground among different actors, in particular among municipalities, associations, and between municipalities and associations.

The second key theme extracted by the empirical data is that agriculture in South Tyrol can essentially be defined as a social, economic, and cultural system well-rooted in the territory. A few interviewees clearly remark on how "agriculture is a political question". Especially important is the role covered by mountain agriculture, characterized by small farms. Most interviewees agree that subsidies for their preservation are necessary; this is because mountain agriculture has a multifunctional role and is thus perceived as important for a variety of reasons. One relevant reason is to take care of the aesthetic value of the agricultural landscape, both for attracting tourists to the region as well as for the residents; another reason is to preserve the hydrogeological equilibrium of the territory (for example, by preventing damages from bad weather, avalanches and/or landslides). Further, according to the interviewees, what justifies the need for subsidies is the cultural aspect, which is the basis of the South Tyrolese society. The cultural dimension includes the concepts of quality, experience, knowledge and taste, which rotate around the centrality of the mountain as a spatial category along with its 'pure', natural food products.

An interviewee has also pointed out the fact that focusing on agriculture makes the LEADER Programme coherent with the main rural development plan. Finally, it is suggested that the LEADER participatory method is a very important tool for increasing the possibilities of survival for small mountain agriculture: LEADER allows and encourages an even closer cooperation with tourism. At the provincial level, it is significant that the current provincial councillor for agriculture has also the task of dealing with tourism (Assessore al turismo e all'agricoltura). According to Tappeiner (Provincia Autonoma di Bolzano 2007, 371), "tourism without agriculture is not sustainable, neither from an economic point of view or an ecological one. This is particularly evident if compared with the situation in the eastern and western Alps, both in Italy and France".

In the current LEADER 2007-2013, this EU method, because of the overarching and powerful structure of agriculture, has led to the exclusion of the other economic sectors. Funding is given to innovative ideas in the agricultural sector, and to other sectors which may have a link with agriculture, such as tourism.

The ties between politics and agriculture are quite strong; as the Südtiroler Bauernbund is one of the most prominent associations in South Tyrol at the political level, it is no surprise that nine out of ten farmers voted for the Südtiroler Volkspartei in the last elections on 26 October 2008, and agriculture is still one of the strongest working groups within the party. The Südtiroler Volkspartei, the German-speaking ethnic party, has ruled the province since the end of the Second World War. In the last elections, even though for the first time the party received 
less than $50 \%$ of the total vote $(48.1 \%)$, it still has the majority of seats in the provincial council (18 of 35). President Durnwalder started his career in the Südtiroler Bauernbund and has been in power since 1989 (almost 20 years); these considerations suggest that farming enjoys a significant position in the development strategies of the political representatives of the province (Südtiroler Bauernbund 2008; Consiglio della Provincia...2008).

\section{Discussion and conclusions}

Upon the background of global processes of neo-liberalization and homogenization, the investigated geo-institutional comparison clearly suggests that policy practices and landscapes represent a unique geographical event, which cannot be left aside neither from its causal/contextual conjunctures, nor from a broad theoretical framework. This is very relevant when dealing with policy-making, because it deeply questions the identification of the so-called 'best policy practices' and/or the borrowing of policies that work. Within a rural development literature dominated by case studies from Northern Europe, this article is very relevant since it shows that the peopling of the countryside by 'new', professional expertise does not have the same weight in different parts of the European Union. Wherever the causal/contextual conjunctures are favourable, the emergence of sub-politics may find fertile ground. In contrast, the traditional representative institutions of the political systems tend to prevail. Within the context of a decision-making process which is increasingly fragmented and complex, the data suggest that the LEADER approach is a hybrid combination between hierarchies and market regulation: although in both case studies clear mechanisms of competition are present, at the same time covert leadership of such approach is carried out by powerful interest groups (whether public or private) which monopolize the flow of resources from the centre to the lagging behind regions (see also Osti 2000).

This article has contributed to bring new vitality to the debate concerning the relation between agency and structure. In light of critical realism, the empirical data generated by the two case studies has shown that structural dimensions pre-exist, and therefore they have to be interpreted not only historically, but also institutionally and territorially; these social structures represent a necessary condition to agency, and thus, they are not the deliberate result of agency. Analytical dualism has allowed explaining the causal interplay between agents and structures, since they both retain a certain degree of autonomy. Based on re-territorialization processes, LEADER partnerships have taken fairly different forms and scopes of action, with different agents dominating others. The empirical data has shown that in some cases, the mediatory role of key human and social agents may have a powerful influence both in shaping and guiding the overarching social structures, and in producing new values through project activity. Beyond the strengthening of cooperation among rural agents (both social and human), these partnerships have resulted in forms of social exclusion.

In the Joensuun Seudun LEADER, the rise of local actors within rural development practices has taken the form of a 'project class' as suggested by Kovách and Kučerová (2006). Their multiple role has to be interpreted in the context of two interconnected traditions. The first tradition is the key social structure of village action and development, which is an inner characteristic of Finnish countryside; the second tradition is given by the fact that development policies (especially after Finland joined the EU) have been to a large extent dominated by civil servants. Within the LEADER approach, this causal/historical background has been favouring on the one hand close cooperation between a variety of organizations for a successful implementation of this rural development programme, and on the other hand competition among human and social agents to have access to financial resources. In the LAG Wipptal instead, LEADER policy practices and landscapes are dominated by the structural dimensions of politics and agriculture. This is in virtue of the traditionally hierarchical South Tyrolese society, which rotates around the centrality of the Bauer, and its relations with the territory, in particular the spatial category of the mountain. It is because of the hierarchical character of society that the LEADER approach in this area is to a large-extent top-down, and is implemented by the most 'representative' organizations at the private, and above all, at the public level. Powerful political agents have inhibited the possible emergence and formation of a coherent 'project class'. Similarly to the Italian context, participatory approaches in South Tyrol do not have solid 
roots in the public administration, political parties, executive bodies and councils, and they are linked to the personal initiative of representatives of the politico-institutional world.

\section{Acknowledgements}

I would like to thank the Foundation Kyösti Haatajan Säätiö, which has allowed me to submit this publication to European Countryside, as well as the Karelian Institute, University of Eastern Finland, for its technical support.

\section{References}

[1] Agnew, J. (2001). The new global economy: time-space compression, geopolitics, and global uneven development. Journal of World-Systems Research 7(2), 133-154.

[2] Alcock, A. (1970). The History of the South Tyrol question. Michael Joseph, London.

[3] Barke, M. \& Newton, M. (1997). The EU LEADER initiative and endogenous rural development: the application of the Programme in two rural areas of Andalusia, Southern Spain. Journal of Rural Studies 13(3), 319-341. Doi: 10.1016/S0743-0167(97)00027-2.

[4] Beck, U. (2006). Power in the global age. Cambridge: Polity Press.

[5] Beck, U. \& Beck-Gernsheim, E. (2005). Individualization. Institutionalized individualism and its social and political consequences. London: Sage Publication.

[6] Beck, U. (1996). World risk society as cosmopolitan society? Ecological questions in a framework of manufactured uncertainties. Theory, Culture \& Society, 13(4), 1-32. Doi: 10.1177/0263276496013004001.

[7] Beck, U., Giddens, A. \& Lash, S. (1994). Reflexive modernization. Politics, tradition and aesthetic in the modern social order. Cambridge: Polity Press.

[8] Borghi, E. (2006). Quali montagne? Dallo stereotipo della montagna alla governance per i sistemi locali montani. In Messina, P. \& Marella, A. (eds.): Eco dei Monti. Politiche per le aree montane a confronto, 21-39. Padova: CLEUP.

[9] Brenner, N., Peck, J. \& Theodore, N. (2010). Variegated neo-liberalization: geographies, modalities, pathways. Global networks, 10(2), 182-222.

[10] Brenner (2004). New State Spaces: Urban Governance and the Rescaling of Statehood. Oxford: Oxford University Press.

[11] Cavazzani, A. \& Moseley, M. (2001). The practice of rural development partnerships in Europe. Soveria Mannelli: Rubbettino Editore.

[12] Cerny, P. G. (2006). Restructuring the state in a globalized world: capital accumulation, tangled hierarchies, and the search for a new spatio-temporal fix. Review of International Political Economy, 13(4), 679-695. Doi: 10.1080/09692290600839931.

[13] Ciapetti, L. (2010). Lo sviluppo locale: capacità e risorse di città e territori. Bologna: II Mulino.

[14] Consiglio della Provincia Autonoma di Bolzano (2008). Risultati delle elezioni provinciali. November 2008. Retrieved from: http://www.provinz.bz.it/vote/landtag2008/home_li_vg.htm

[15] Corbin, J. \& Strauss, A. (1990). Grounded theory research: procedures, canons, and evaluative criteria. Qualitative Sociology 13(1), 3-21.

[16] Dolowitz, D. P. \& Marsh, D. (2000). Learning from abroad: the role of policy transfer in contemporary policy-making. Governance: an international journal of policy and administration, 13(1), 5-24. Doi: 10.1111/0952-1895.00120.

[17] Emirbayer, M. \& Mische, A. (1998). What is agency? The American Journal of Sociology, 103(4), 962-1023. Doi: 10.1086/231294. 
[18] ESPON (2010). European perspective on specific types of territories. Retrieved from: http://www.espon.eu/export/sites/default/Documents/Projects/AppliedResearch/GEOSPEC S/GEOSPECS_Interim-Report_16-03-2011.pdf.

[19] EU Council Regulation (EC) No 1698/2005 (2005). Retrieved from: http://eurlex.europa.eu/LexUriServ/LexUriServ.do?uri=OJ:L:2005:277:0001:0040:EN:PDF.

[20] Fairclough, N. (2004). Analysing discourse: textual analysis for social research. London: Taylor \& Francis.

[21] Fait, S. \& Fattor, M. (2010). Contro I miti etnici. Alla ricerca di un Alto Adige diverso. Bolzano: Raetia.

[22] Fuchs, S (2001). Beyond agency. Sociological theory, 19(1), 24-40. Doi: 10.1111/07352751.00126.

[23] Gatterer, C. (2007). In lotta contro Roma. Cittadini, minoranze e autonomie in Italia. Bolzano: Edizioni Praxis 3.

[24] Giddens, A. (1984). The constitution of society: outline of the theory of structuration. Berkeley: University of California Press.

[25] Giddens, A. (1979). Central problems in social theory: action, structure and contradiction in social analysis. London: McMillan Press.

[26] Gløersen, E., Dubois, A., Copus, A. \& Schürmann, C. (2005). Northern peripheral, sparsely populated regions in the European Union. Stockholm: Nordregio.

[27] Gruppo di Azione Locale Wipptal (2008). Piano di Azione Locale LEADER 2007-2013. Retrieved from http://www.provincia.bz.it/agricoltura/download/PSL_Alta_Val_Isarco.pdf.

[28] Hautamäki, L. (1989). Elävä kylä, elävä kotiseutu, elävä Suomi: kylätoiminnan tausta, synty, ja laajeneminen kansanliikkeksi. Helsinki: Kyläasiain neuvottelukunta.

[29] High, C. \& Nemes, G. (2007). Social Learning in LEADER: exogenous, endogenous and hybrid evaluation in rural development. Sociologia Ruralis 47(2), 103-119. Doi: 10.1111/j.1467-9523.2007.00430.x.

[30] Holzer, B. \& Sørensen, M. P. (2003). Rethinking subpolitics. Beyond the 'iron cage' of modern politics? Theory, Culture \& Society, 20(2), 79-102. Doi: $10.1177 / 0263276403020002005$.

[31] Hyyryläinen, T., Nousiainen, M. \& Pylkkänen, P. (2009). Finnish rural policy governance in the project society. Presentation given at the World Conference in rural sociology in Vaasa, 2009.

[32] Hyyryläinen, T. (2000). Kylätoiminnan perinne ja hanketoiminta. In Hyyryläinen, T. \& Rannikko, P. (eds.): Eurooppalaistuva maaseutupolitiikka, (pp. 108-119). Tampere: Vastapaino.

[33] Istituto provinciale di statistica (2012). Censimento della popolazione 2011. Determinazione della consistenza dei tre gruppi linguistici della Provincia Autonoma di Bolzano-Alto Adige. Provincia Autonoma di Bolzano-Alto Adige, Bolzano. Retrieved from: http://www.provinz.bz.it/astat/it/popolazione/439.asp?demographischestruktur_action=4\&de mographischestruktur_article_id=198730.

[34] Joensuun Seudun LEADER Yhdistys (2007). Joensuun seudun Leader+ ohjelma 20002006. Retrieved from http://joensuu-leader.info/images/stories/leader-ohjelma.pdf.

[35] King, N. \& Horrocks, C. (2010). Interviews in qualitative research. Thousand Oaks: Sage.

[36] Kull, M. (2008). EU Multi-level governance in the making: the community initiative LEADER+ in Finland and Germany. Helsinki: University of Helsinki.

[37] Kovách, I. \& Kučerová, E. (2006). The project class in Central Europe: the Czech and Hungarian cases. Sociologia Ruralis, 46(1), 3-21. Doi: 10.1111/j.1467-9523.2006.00403.x 
[38] Layder, D. (1998). The reality of social domains: implications for theory and method. In May T. \& Williams M. (eds.): Knowing the social world (pp. 86-102). Buckingam: Open University Press.

[39] LEADER achievements: a diversity of territorial experience (2007). Portugal: LEADER+ Observatory Conference.

[40] Lechner, O., Moroder, B. \& Mahlknecht, A. (2010). Ritratto economico dell'Alto Adige. Bolzano.

[41] Lewis, P. A. (2002). Agency, structure and causality in political science: a comment on Sibeon. Politics 22(1), 17-23. Doi: 10.1111/1467-9256.00154.

[42] Lowndes, V. \& Wilson, D. (2001). Social capital and local governance: exploring the institutional design variable. Political Studies 49(4), 629-647. Doi: 10.1111/14679248.00334.

[43] Markusse, J. (1997). Power-Sharing and 'Consociational Democracy' in South Tyrol. GeoJournal 43(1), 77-89. Doi: 10.1023/A:1006868822977.

[44] Ministry of Agriculture and Forestry (2011). Manner-Suomen maaseudun kehittämisohjelma vuosiraportti 2010, Leader-työ LUONNOS. Ohjelman seuranta, toimintalinja 4. Toimenpiteiden toteutuminen tavoitteisiin nähden. Unpublished document, Helsinki.

[45] Mori, E. \& Hintner, W. (2009). Il maso chiuso. La sua storia e la normativa vigente. Bolzano: Provincia Autonoma di Bolzano.

[46] North, D. (1990). Institutions, institutional change, and economic performance. Cambridge: Cambridge University Press.

[47] OECD (2009). OECD Rural Policy Reviews: Italy. OECD, Paris.

[48] OECD (2008). OECD Rural Policy Reviews: Finland. Paris: OECD.

[49] Peck, J. (2011). Geographies of policy: from transfer-diffusion to mobility-mutation. Progress in Human Geography, 35(6), 773-797. Doi: 10.1177/0309132510394010.

[50] Osti, G. (2000). LEADER and partnerships: the case of Italy. Sociologia Ruralis, 40(2), 172180. Doi: 10.1111/1467-9523.00139.

[51] Petrella, A. (2009). Innovazioni e resistenze nello sviluppo rurale italiano. In Ruzza, C., Bozzini, E., Crivellari, P. \& Petrella, A. (eds.): Europa e territorio: governance rurale, partecipazione, sostenibilità, (pp. 151-191). Catanzaro: Rubettino Università.

[52] Polelli, M. (1968). Aspetti economici e sociali del maso chiuso. Galliano: Manfrini.

[53] Provincia Autonoma di Bolzano-Alto Adige/Autonome Provinz Bozen-Südtirol (2009). Punti di svantaggio nell' agricoltura di montagna.

[54] Provincia Autonoma di Bolzano-Alto Adige/Autonome Provinz Bozen-Südtirol (2007). Rapporto annuale di esecuzione. LEADER+ (periodo 2000-2006). Unpublished document. Retrieved from http://www.provincia.bz.it/agricoltura/service/pubblicazioni.asp.

[55] Pyy, I. \& Lehtola, I. (1996). Nordic Welfare State as Rural Policy. Finnish Journal of Rural Research and Policy (Maaseudun Uusi Aika) 3, 17-34.

[56] Ray, C. (2001). Transnational co-operation between rural areas: elements of a political economy of EU rural development. Sociologia Ruralis, 41(3), 279-295. Doi: 10.1111/14679523.00183.

[57] Ray, C. (1998). Culture, intellectual property and territorial rural development. Sociologia Ruralis 38(1), 3-20. Doi: 10.1111/1467-9523.00060.

[58] Ray, C. (1997). Towards a theory of the dialectic of local rural development within the European Union. Sociologia Ruralis, 37(3), 345-362. Doi: 10.1111/j.14679523.1997.tb00055.x. 
[59] Ruzza, C., Bozzini, E., Crivellari, P. \& Petrella, A. (2009). Europa e territorio: governance rurale, partecipazione, sostenibilità. Catanzaro: Rubbettino.

[60] Salvato, M. (2006). Vivere in montagna come scelta e non come destino. Riflessioni sullo sviluppo delle areee montane. In: Messina, P. \& Marella, A., eds, Eco dei Monti. Politiche per le aree montane a confronto (pp. 2225-239). Padova: CLEUP.

[61] Sawyer, K. (2002). Unresolved tensions in sociocultural theory: analogies with contemporary sociological debates. Culture and Psychology 8(3), 283-305. Doi: $10.1177 / 1354067 X 0283002$.

[62] Schmidt-Thomé K., \& Vihinen, H. (2006). Rural areas- urban-rural interaction and beyond. In Eskelinen, H., \& Hirvonen, T., eds., Positioning Finland in a European space (pp. 41-53). Helsinki: Ministry of the Environment and Ministry of the Interior.

[63] Sewell, W. H. (1992). A theory of structure: duality, agency, and transformation. American Journal of Sociology, 98(1), 1-29.

[64] Shucksmith, M. (2010). Disintegrated rural development? Neo-endogenous rural development, planning and place-sharing in diffused power contexts. Sociologia Ruralis, 50(1), 1-14. Doi: 10.1111/j.1467-9523.2009.00497.x.

[65] Sibeon, R. (2000). Governance and the policy process in contemporary Europe. Public Management Review 2(3), 289-310. Doi: 10.1080/14719030000000019.

[66] Sjöblom, S. (2006). Introduction: towards a projectified public sector - project proliferation as a phenomenon. In Sjöblom, S., Andersson, K., Eklund E., \& Godenhjelm, S., eds., Project Proliferation and Governance - the Case of Finland (pp. 9-31). Helsinki: University of Helsinki, Swedish School of Social Science.

[67] Suddaby, R. (2006). From the editors: what grounded theory is not. Academy of Management Journal 49(4), 633-642. Doi: 10.5465/AMJ.2006.22083020.

[68] Tilastokeskus (2011). Maakuntien pinta-ala, väestö. Retrieved from www.stat.fi.

[69] Südtiroler Bauernbund (2008). Bauernstand steht kompakt zusammen. December 2008. Retrieved from www.sbb.it.

[70] Tykkyläinen, M. (2008). Methodological starting points in the research of community and spatial change. In Rautio, V., \& M. Tykkyläinen, eds, Russia's northern regions on the edge. (pp. 9-24). Helsinki: Gummerus Printing.

[71] Uusitalo, E. (2011). LEADER in Finland, Russia, and Africa. Unpublished paper presented at the LAGS' Global Networks Seminar, Ellivuori, Sastamala, Finland. 